UDC: $159.922 .6: 159.923 .2$

DOI: https://doi.org/10.24195/2414-4665-2017-7-18

\author{
Lyubov Spivak, \\ Doctor of Psychology, associate professor, \\ Department of Theoretical and Counselling Psychology, \\ National Pedagogical Dragomanov University, \\ 9, Pyrohova Str., Kyiv, Ukraine
}

\title{
TRANSFORMATIONS OF PERSONALITY'S NATIONAL SELF-CONSCIOUSNESS IN YOUTH
}

The article deals with the results of empirical research of transformations of personality's national self-consciousness according to the types of national identity in youth. Transformational tendencies of the development of personality's national self-consciousness in youth according to the types of national identity were studied by means of a method "Types of ethnic identity" (by G. Soldatova, S. Ryzhova). The survey involved 1303 respondents of Ukrainian nationality aged from 17 to 22. In general, age dynamics of the development of personality's national self-consciousness in youth according to the types of national identity is positive. Namely, starting from the age of 17-18 up to 21-22 the number of the respondents with national self-consciousness according to "positive national identity" type slightly increases. They have positive image of their nation and positive attitude towards it which optimally correlates with their tolerant attitude towards other ones. At the same time, it has been revealed that from the age of 17-18 to 21-22 the amount of the respondents with national self-consciousness according to transformed types of national identity slightly decreases. This much smaller number of young people possesses the following characteristics: the irrelevance of nationality, values and features of their nation; uncertainty of their national belonging, etc. The research outcomes can be applied when organizing psychological support for the development of university students' national self-consciousness.

Keywords: national self-consciousness, types of national identity, transformations, development, personality, youth.

\section{Introduction}

Continuous integration of Ukraine into the European national and cultural space emphasises the issue of the development of national self-consciousness of its citizens. The leading task of the State Programme of National and Patriotic Upbringing of Children and Youth is to ensure a high level of personality's national self-consciousness. However, the implementation of this scheduled task is complicated under conditions of socio-political and socioeconomic transformations in the country. Therefore, in the context of these urgent public needs the emphasis is being put on the research which is focused on the development of personality's national self-consciousness in youth.

Psychological science has focused only on certain aspects of this issue: the psychological factors of the development of personality's national self-consciousness in youth (A. Berezin, 2002); features of the formation of national self-consciousness of university students in the process of studying a foreign language (O. Barkanova, 2006); students' comprehension of the works of Ukrainian literature and academic disciplines focused on Ukrainian studies as a means of students' national selfconsciousness development (V. Sokolova, 2009).

It should be remembered that that the young age is characterised by the intensification of group identity processes, including those concerning the nation. At the same time, the transformation of national identity which occurs during the crisis periods of the national development, contributes to changes in the image of the nation and personality's attitude towards their and other nations [1], which, in our understanding, are the elements of the personality's national consciousness and national selfconsciousness [2]. In other words, the transformations of national identity lead to changes in personality's national self-consciousness.

According to G. Soldatova, positive national identity which is inherent to most people is a norm and any deviation from it is considered to be a transformation. The scientist believes that national self-consciousness which is formed by positive national identity reflects people's tolerant attitude towards the representatives of their and other nations. Citizens' desire for positive national identity is a prerequisite for the integrity, stability and independence of the nation, its peaceful interaction with other nations and cultures in the multinational world space. Assuming positive national identity, in the structure of personality's national self-consciousness there is an optimal correlation between a positive image of his/her own nation and positive attitude towards his/her own and other nations, their values and representatives. However, a personality with positive national identity gives preference to the values of his/her own nation.

G. Soldatova believes that positive national identity is more about a personality's one and the transformation of national identity is more about group identity. The transformations of national identity can be manifested in the irrelevance of nationality; the uncertainty of nationality; preferring not the nation but other ethnic groups; the tendency to discriminate other nations or national minorities. 
We distinguish the following types of transformed national identity: hypoidentity (national nihilism), national indifference and hyperidentity (national egoism, national isolationism and national fanaticism). The indicators of transformed national self-consciousness according to hypoidentical type are personality's unwillingness to share the values of his/her nation; a sense of inferiority; feeling of shame and occasional manifestations of negativism towards the representatives of his/her own nation and difficulties in communicating with them; alienation from his/her own nation.

Manifestations of a transformed national selfconsciousness according to hyperidentical type are the following: the desire of the representative of a certain nation to dominate over other ones; national intolerance (from being irritated by the presence of the representatives of other nations to the restriction of their rights and opportunities); negative image of other nations and hostility towards their representatives. Thus, a transformed national self-consciousness according to "national egoism" type which is the most loyal among the hyperidentical types, can be manifested in tension and irritation in the process of interaction with the representatives of other nations, in recognizing the rights of one's own nation to solve different problems at the expense of other nations; or at the verbal level by using the "my nation" concept in the interethnic interactions. The development of a transformed national self-consciousness according to "national isolationism" type which is a type of hyperidentity is manifested in personality's belief in the superiority of his/her nation, in the necessity of preserving the purity of the national culture; negative attitude towards the interethnic marriages; xenophobia. Manifestations of the transformed national self-consciousness according to "national fanaticism" type, which also belong to hyperidentity types are as follows: people's willingness to perform all actions (up to the ethnic cleansing) in the interests of their nations which are understood by these people too subjectively; the deprivation of the representatives other nations of their social privileges and rights to use the resources of their nations; recognition of the priority of the national rights over human rights; the justification of all sorts of sacrifices in the struggle for the prosperity of the nation [2].

The paper aims to examine the transformations of personality's national self-consciousness in youth according to the types of national identity.

\section{Research Methods}

Transformational tendencies of the development of personality's national self-consciousness in youth according to the types of national identity were studied by means of Types of Ethnic Identity Inventory (by G. Soldatova, S. Ryzhova) [1]. For each type (positive national identity, national indifference, national nihilism, national egoism, national isolationism, national fanaticism) a respondent could get between -10 and 10 points. The number of points demonstrated the following levels: between -10 and -4 points - low; between -3 and 3 - middle; between 4 and $10-$ high. 1303 respondents of Ukrainian nationality aged 17-22 (namely: 263 people aged 17-18, 261 people aged 18-19, 259 people aged 19-20, 262 people aged 20-21 and 258 people aged 21-22) who were students of higher education institutions from different cities of Ukraine (e.g. Kyiv, Rivne, Berdyansk and KamyanetsPodilsky) took part in the experiment.

\section{Research Results}

Quantitative characteristics of age dynamics of personality's national self-consciousness transformation in youth according to the types of national identity which were obtained through the application of the abovementioned method are demonstrated in Table 1.

Table 1 demonstrates that national selfconsciousness of many respondents of all age groups is developed according to positive national identity type (which is a norm). National self-consciousness of other respondents is transformed according to the following types of national identity as national nihilism and national isolationism - the minimum number of individual age groups; national indifference, national egoism, national fanaticism and a combination of two types - a small number of almost all age groups. It should be noted that the level of national self-consciousness, regardless of the type, in all the respondents was either high or medium; the low level was not detected. Table 1 also demonstrates that, in general, age dynamics of the development of personality's national self-consciousness in youth according to the type of national identity is positive. Its features are described below.

The carried out quantitative analysis has shown that from the age of 17-18 to the age of 21-22 the number of young boys and girls whose national self-consciousness develops according to "positive national identity" type (normal), slightly increases (namely: from $82.14 \%$ of people aged $17-18$ to $89.14 \%$ of people aged 21-22). Thus, it has been established that the level of national self-consciousness according to the type of positive national identity is high in most of them (from $76.82 \%$ of people aged $17-18$ to $85.06 \%$ of people aged 18-19). In general, young people with this level are characterised by the following features: axiological attitude to the values of their nation (language and culture) which correlates with positive attitude towards other nations; respect towards the representatives of their nation combined with tolerant attitude towards the representatives of other nations; preferring values and lifestyle of their nation. Thus, the respondent K. M. (19 years old) with this level said: "I respect the culture of other nations, they all are interesting for me and I learn a lot for my spiritual enrichment, but I never forget about my origin and that my motherland is Ukraine". 
Table 1.

Quantitative indicators (\%) of personality's national self-consciousness

transformation in youth according to the types of national identity $(n=1303)$

\begin{tabular}{|c|c|c|c|c|c|c|}
\hline \multirow[b]{2}{*}{ Type of national identity } & \multirow[b]{2}{*}{ Levels } & \multicolumn{5}{|c|}{ Age groups } \\
\hline & & $\begin{array}{l}\infty \\
\frac{1}{1} \\
\stackrel{\mathbb{N}}{I}\end{array}$ & $\begin{array}{l}0 \\
0 \\
0 \\
0 \\
0\end{array}$ & 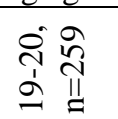 & 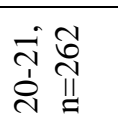 & 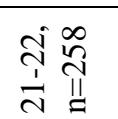 \\
\hline \multirow{3}{*}{ Positive national identity } & high & 76.82 & 85.06 & 79.92 & 77.48 & 79.84 \\
\hline & medium & 5.32 & 5.74 & 7.72 & 6.49 & 9.3 \\
\hline & low & - & - & - & - & - \\
\hline \multirow{3}{*}{ National indifference } & high & 4.94 & 2.68 & 1.55 & 1.53 & 3.87 \\
\hline & medium & 2.66 & - & 0.77 & 1.91 & - \\
\hline & low & - & - & - & - & - \\
\hline \multirow{3}{*}{ National nihilism } & high & - & - & - & 0.76 & - \\
\hline & medium & - & - & 0.77 & - & - \\
\hline & low & - & - & - & - & - \\
\hline \multirow{3}{*}{ National egoism } & high & 2.66 & 1.53 & 1.55 & 0.76 & 0.78 \\
\hline & medium & - & 0.77 & 0.77 & - & - \\
\hline & low & - & - & - & - & - \\
\hline \multirow{3}{*}{ National isolationism } & high & - & - & - & 1.91 & 0.78 \\
\hline & medium & - & - & 0.77 & 1.53 & - \\
\hline & low & - & - & - & - & - \\
\hline \multirow{3}{*}{ National fanaticism } & high & 2.66 & - & 1.93 & 1.53 & 0.78 \\
\hline & medium & - & - & 0.77 & - & - \\
\hline & low & - & - & - & - & - \\
\hline \multirow{3}{*}{ Combination of two types } & high & 4.94 & 3.45 & 1.93 & 1.91 & 1.94 \\
\hline & medium & - & 0.77 & 1.55 & 4.19 & 2.71 \\
\hline & low & - & - & - & & - \\
\hline Total & & 100 & 100 & 100 & 100 & 100 \\
\hline
\end{tabular}

According to some of the above-mentioned characteristics we have noticed some features of age dynamics. Thus, there are almost three times as much of the respondents from the age of 17-18 to the age of 21-22 who "agree" or "rather agree than disagree" with the following statement: "I'm the kind of person who prefers the way of life of my nation, but I show great interest in other ones". These features indicate the formation of young people's positive attitude towards the way of life of the nation to which they belong, and the emergence of significant interest in other nations, namely, cultures, lifestyle features of national character of their representatives, etc. We believe the following aspect should be emphasised: all the respondents with a high level of national selfconsciousness according to "positive national identity" type do not conceal their own nationality. They are proud of their belonging to the Ukrainian nation which has a majestic history, authentic culture, traditions, customs, beautiful scenery, melodic language, etc.

Concerning age dynamics of a relatively high level of national self-consciousness according to "positive national identity" type, it should be emphasised that from the age of 17-18 to the age of 21-22 years the number of the respondents who to a lesser extent ("rather agree than disagree") agree with the statement about the combination of love for their nation with respect towards the language and culture of other nation slightly increases. In our opin- ion, these features are due to the fact that with age, young people pay more attention to the interethnic and intercultural differences. Thus, it has been empirically found that from the age of 17-18 to 21-22 years there are almost three times as much of the number of the respondents who are not ready to interact with representatives of other nations and ignore ethnic differences.

The medium level of national self-consciousness which is developed according to "positive national identity" type was found in a small number of young boys and girls, namely: from $5.32 \%$ of people aged $17-18$ to $9.3 \%$ of people aged 21-22. The respondents with this level are characterised by the following features: axiological attitude towards certain features of their nation (language, culture, territory) which correlates with positive attitude towards some features of other nations; respect for certain features of the representatives of their nation combined with tolerant attitude towards certain features of the representatives of other nations; giving preferences to some values and ways of life of their nation. However, it should be emphasised that the respondents with both high and medium levels of self-national consciousness according to "positive national identity" type are proud of their belonging to the Ukrainian nation.

In comparison with "positive national identity" type, national self-consciousness according to various types of transformed national identity (e.g. national nihilism, na- 
tional indifference, national egoism, national isolationism and national fanaticism) was fixed in a small number of the respondents. While describing age dynamics according to these indicators, it should be noted that from the age 17-18 to 21-22 the number of young boys and girls which differ by their transformed national selfconsciousness decreases (namely: from $12.92 \%$ to $6.21 \%$, respectively).

Thus, national nihilism which is characterized by dominant feelings of inferiority about one's own national identity, giving preferences to the representatives of other nations, feelings of shame and contempt for the representatives of one's own nation was recorded in a very small number of respondents aged 19-20 (0.77\% - medium level) and respondents aged 20-21 (0.76\% - high level).

The high level of transformed national selfconsciousness according to national indifference type was recorded in a small number of the respondents: from $4.94 \%$ of people aged $17-18$ to $1.53 \%$ of people aged 20 21. This level was reflected by their full acceptance of a number of the following statements: in everyday communication the nationality is irrelevant; I don't care about my national identity; I don't give preference to any culture including my own one; my nation is neither worse nor better than other ones; all rights to use natural and social resources on the territory of a particular nation must belong to it. Thus, the respondent M. K. (17 years old) expressed his position in the following way: "I will live in a country where I will feel more comfortable. It doesn't matter whether this country is Ukraine or not. I don't consider myself as a person who clearly belongs to the Ukrainian nation".

The medium level of transformed national selfconsciousness according to "national indifference" type was detected in a few boys and girls of the following age groups: $17-18$ (2.66\%), 19-20 (0.77\%), 20-21 (1.91\%). They are less likely to agree (rather agree than disagree, somewhat agree and somewhat disagree, rather disagree than agree) that they possess the above-mentioned characteristics. It should be noted that many respondents with high and medium levels of transformed national selfconsciousness according to "national indifference" type identified themselves as a globally-minded people, "cosmopolitans", "Slavs", etc.

A small number of the respondents $(2.66 \%$ aged 17 18; nearly $1.5 \%$ aged $18-19$ and $19-20$; nearly $0.8 \%$ aged 20-21 and 21-22) demonstrated a high level of transformed national self-consciousness according to "national egoism" type. They believe that the nation to which they belong and the lifestyle of its representatives are the best; they feel irritated under conditions of close interaction with the representatives of other nations; they feel tense when they hear another language; they are sure that interactions with the representatives of other nations often lead to troubles. Few young people $(0.77 \%$ of people aged 18 19 and 19-20) with the medium level of transformed national self-consciousness according to this type, possess these characteristics to a certain extent. They believe that their nation is one of the best nations; they are happy to communicate only with the representatives of certain nations.

Transformed national self-consciousness according to "national isolationism" type was found only in few young boys and girls over the age of 19. According to the position of the respondents with the high level (1.91\% of people aged 20-21; $0.78 \%$ of people aged 21-22), the representatives of their nation are more developed or gifted in comparison with the representatives of other nations; their fellow countrymen have the right to solve their own problems at the expense of other nations; interethnic marriages ruin the nation; real friendship is possible only between people of the same nationality; the culture of the nation must be protected from the influence of other cultures. The respondents with the medium level of transformed national self-consciousness according to this type $(0.77 \%$ of people aged $19-20$ years; $1.5 \%$ of people aged 20-21) to a lesser extent agree (somewhat agree and somewhat disagree) with these statements.

A small number of the respondents of almost all age groups, except for people aged 18-19 years, demonstrated the high level of national self-consciousness transformed according to national fanaticism type, namely: from $2.66 \%$ of people aged $17-18$ to $0.78 \%$ of people aged 21 22. In their opinion, "national rights are above human rights"; "in order to protect national interests all means are good"; "preservation of the purity of the nation is a must"; "on one's national territory it is necessary to restrict the rights of representatives of other nations". The medium level of the transformed national selfconsciousness according to this type which is characterised by partial acceptance of the above-mentioned statements was identified in only $0.77 \%$ of those aged $19-20$.

A combination of two types of national selfconsciousness (namely, national self-consciousness according to "positive national identity" type with one of the transformed types - national egoism, national indifference or national isolationism), that is, the same quantitative indicators, were recorded in a small number of the respondents of all age groups. Regarding age dynamics of the identified combinations it has been established that from the age of $17-18(4.94 \%)$ to $21-22(1.94 \%)$ the number of young boys and girls with the high level slightly decreases and the number of those with the medium level slightly increases (from $0 \%$ of people aged $17-18$ to $2.71 \%$ of people aged 21-22). Qualitative characteristics of such combinations unite the above-mentioned descriptions of different types of identity. It should be noted that statistically significant differences in the studied indicators (national self-consciousness according to the types of national identity) or their combinations between the respondents of different age groups which were checked by the criterion $\varphi^{*}$ of Fisher transformation, were not detected.

\section{Conclusions}

Thus, the results of the experimental study of transformations of personality's national self-consciousness in 
youth according to the types of national identity makes it possible to summarize the following. In general, it has been established that age dynamics of the development of personality's national self-consciousness in youth is positive. Namely, from the age of 17-18 to 21-22 the number of young boys and girls with national self-consciousness according to "positive national identity" type slightly increases. They have formed a positive image of their nation and a positive attitude towards it which optimally correlates with their tolerant attitude towards other nations. In addition, they give their preference to the values of their nation. At the same time, it has been revealed that

\section{REFERENCES}

1. Soldatova, G. U. (1998). Psikhologiya mezhetnicheskoy napryazhonnosti [Psychology of Interethnic Tension]. Moscow: Smysl [in Russian].

\section{ЛІТЕРАТУРА}

1. Солдатова Г. У. Психология межэтнической напряженности / Г. У. Солдатова. - М. : Смысл, 1998. -389 c. from the age of $17-18$ to $21-22$ the amount of the respondents with national self-consciousness according to transformed types of national identity slightly decreases. This much smaller number of young people possesses the following characteristics: the irrelevance of nationality, values and features of their nation; uncertainty of their national belonging; giving preferences not to the nation but to other social groups; predisposition to the discrimination of national minorities. Closer attention should be paid to the factors of the development of personality's national self-consciousness in youth according to the transformed types of national identity.

2. Spivak, L. N. (2014). Psychological Foundations for the Development of the Young Person's National SelfConsciousness. - European Applied Sciences, 1, 94-96 [in English].

2. Spivak L. N. Psychological Foundations for the Development of the Young Person's National SelfConsciousness / L. N. Spivak // European Applied Sciences. - 2014. - № 1. - P. 94-96.

доктор психологічних наук, доцент кафедри теоретичної та консультативної психологї̈, Національний педагогічний університет імені М. П. Драгоманова, вул. Пирогова, 9, м. Київ, Украӥна

\section{ТРАНСФОРМАЦІЇ НАЦІОНАЛЬНОЇ САМОСВІДОМОСТІ ОСОБИСТОСТІ В ЮНОСТІ}

У статті охарактеризовано результати емпіричного дослідження трансформацій національної самосвідомості особистості за типами національної ідентичності в період юності. Трансформаційні тенденції розвитку національної самосвідомості юнацтва за типами національної ідентичності вивчалися за допомогою методики «Типи етнічної ідентичності» (авт. Г. У. Солдатова, С. В. Рижова). За кожним типом (позитивна національна ідентичність, національна індиферентність, націонігілізм, націоегоїзм, націоізоляціонізм, національний фанатизм) респондент міг набрати від -10 до +10 балів. Кількість набраних балів засвідчувала певні рівні: від -10 до $-4-$ низький; від -3 до 3 - середній; від 4 до 10 - високий. Контингент досліджуваних склали 1303 респонденти української національності 17-22 рр. (студенти вищих навчальних закладів із різних міст України). Встановлено, що загалом вікова динаміка розвитку національної самосвідомості особистості за типами національної ідентичності в юності є позитивною. Зокрема виявлено, що від 17 до 22 років незначною мірою збільшується кількість респондентів із національною самосвідомістю за типом «позитивна національна ідентичність» (норма). У них сформовано позитивний образ своєї нації та позитивне ставлення до неї, що узгоджуються з їх толерантним ставленням до інших націй. Також вони надають перевагу цінностям своєї нації. Окрім цього, зафіксовано, що несуттєво зменшується кількість досліджуваних із національною самосвідомістю за типами «націонігілізм», «національна індиферентність», «націоегоїзм», «націоізоляціонізм», «національний фанатизм» (трансформації). Їм властиві такі характеристики, як-от: неактуальність національності, цінностей і ознак своєї нації; невизначеність національної належності; надання переваги не нації, а іншим соціальним групам; схильність до дискримінації національних меншин чи до самоприниження перед представниками інших націй. Одержані результати можуть бути використані під час організації психологічного супроводу розвитку національної самосвідомості у студентів вищих навчальних закладів.

Ключові слова: національна самосвідомість, типи національної ідентичності, трансформації, розвиток, особистість, юність. 